\title{
Pengaruh Rasio Keuangan Terhadap Return Saham Pada Industri Semen di Indonesia
}

\author{
Hananda Priyandaru \\ Universitas Bina Sarana Informatika \\ E-mail: hanandap@gmail.com
}

Cara Sitasi: Priyandaru, H. (2019). Pengaruh Rasio Keuangan Terhadap Return Saham Pada Industri Semen di Indonesia. Widya Cipta, 3(1), 135-142.

\begin{abstract}
This study aimed to examine the effect of financial ratios on stock returns, either individually per variable or effect simultaneously. This study is causal comparative, by knowing the relationship and the influence of independent variables on the dependent variable. The object of this research is in Indonesian cement companies that has already go public. This research is based on the fact that the secondary data obtained from the Jakarta Stock Exchange during the five years, namely 2009, 2010, 2011, 2012 and 2013. The data analysis was conducted using pooled cross-section time series, with eviews 8 program. Result of hypothesis examination showed that of the six hypotheses proposed, assuming a confidence level ( $\alpha=5 \%)$, there is an accepted hypothesis and assumptions are used when the confidence level $(\alpha=10 \%)$, there are two hypotheses are accepted. At the 5\% level of confidence accepted hypothesis is the hypothesis 2 (there is influence between solvency ratio on stock returns). At the 10\% confidence level accepted hypothesis is the hypothesis 2 (there is influence between solvency ratio on stock returns) and hypothesis 3 (there is the influence of the ratio of activity on stock returns). Furthermore, with a confidence level $(\alpha=5 \%)$, then the hypothesis is rejected hypothesis 1 , hypothesis 3, hypothesis 4, hypothesis 5 and hypothesis 6.
\end{abstract}

Keywords: Financial Ratio, Stock Returns, Eviews 8

\section{PENDAHULUAN}

Indonesia adalah negara yang sedang berkembang, pembangunan demi pembangunan akan terus selalu dibuat. Pembangunan fisik yaitu berupa bangunan gedung, bangunan sekolah, jalan tol, jembatan dan rumah-rumah menjadi contoh pembangunan fisik yang paling kasat mata. Dalam pembangunan fisik tersebut tentunya diperlukan bahan utama bangunan yaitu berupa semen.

Industri semen di Indonesia akan terus ditingkatkan baik secara mutu maupun kapasitasnya, sejalan dengan meningkatnya permintaan semen di Indonesia. Asosiasi Industri Semen Indonesia (ASI) menyatakan bahwa tingkat konsumsi semen di Indonesia mengalami pertumbuhan $8,7 \%$ dengan total volume 13,5 juta ton per tahun.

Harian Bisnis Indonesia (30 Juli 2013;13) menyebutkan, bahwa kinerja semen Indonesia melampaui rata-rata industri. Selanjutnya disebutkan bahwa kinerja salah satu industri perusahaan PT Semen Indonesia (Persero) Tbk. mencatatkan pertumbuhan penjualan diatas rata-rata industri lainnya.

Muhammad Teguh (2013) menjelaskan lebih lanjut tentang pendapat Howe (1978) bahwa teori perusahaan telah digunakan kedalam empat cara. Pertama, teori perusahaan dapat berarti analisis yang berkaitan dengan bagaimanakah tujuan organisasi bisnis ditentukan. Dalam teori perusahaan disebut digunakan pendekatan organisasi atau pendekatan perilaku.

Kedua, teori perusahaan menunjukkan perkembangan tehnik-tehnik yang digunakan perusahaan dalam usahanya untuk mencapai tujuan khusus, termasuk didalamnya teori keputusan, riset operasional dan pemrograman.

Ketiga, teori perusahaan menguraikan analisis mengenai reaksi perusahaan terhadap perubahan lingkungan.

Keempat, teori perusahaan merupakan gabungan pendekatan perilaku perusahaan. Masing-masing pelaku pasar dalam kegiatan bisnis dapat saja memiliki tujuan yang berbeda-beda. Bagi perusahaan swasta tujuan utamanya adalah memaksimumkan keuntungan dan apresiasi modal.

Rasio keuntungan menurut Harahap (2009) dapat diukur dengan beberapa indikator yaitu melalui net profit margin (NPM), return on asset (ROA), return on equity (ROE), return on investment (ROI) dan earning per share (EPS). Rasio keuntungan tersebut dipakai untuk mengukur tingkat keuntungan yang diperoleh perusahaan. Semakin besar tingkat keuntungan perusahaan menunjukkan semakin baik para manajemen perusahaan dalam mengelola perusahaan. Jika ditinjau dari segi investor maka tingginya angka keuntungan akan semakin 
mendorong pemodal besar lain untuk masuk kedalam bisnis tersebut sedangkan bagi investor lain yang cukup dengan membeli saham di bursa, untuk mendapatkan tingkat return saham yang diharapkan.

\section{Laporan Keuangan}

Harahap (2009) menyatakan, bahwa dalam perekonomian modern laporan keuangan merupakan media penting dalam proses pengambilan keputusan ekonomis. Laporan keuangan diterbitkan secara periodik bisa secara tahunan, semester, triwulan, bulanan, bahkan bisa harian.

Lebih lanjut Juan dan Wahyuni (2012) menggambarkan bahwa kerangka dasar penyusunan dan penyajian laporan kuangan (KDPPLK) secara spesifik membahas tentang:

a. Tujuan Laporan Keuangan

b. Karakteristik kualitatif yang menentukan manfaat informasi dalam laporan keuangan

c. Definisi, pengakuan, dan pengukuran unsurunsur yang membentuk laporan keuangan

d. Konsep modal dan pemeliharaan modal

Dari pernyataan diatas dapat diambil pengertian bahwa laporan keuangan menyediakan informasi mengenai posisi keuangan, kinerja, dan perubahan posisi keuangan suatu perusahaan. Laporan keuangan juga menyediakan informasi yang bermanfaat dalam pengambilan keputusan yang dilakukan oleh banyak pengguna.

Horrison et al., (2011) menyatakan bahwa akuntansi merupakan bahasa bisnis. Semakin baik memahami bahasa tersebut, maka anda dapat mengelola keuangan anda serta bisnis anda. Lebih lanjut dikatakan bahwa akuntansi merupakan suatu sistim informasi, yang mengukur aktivitas binis, memproses data menjadi laporan, dan mengomunikasikan hasilnya kepada para pengambil keputusan yang dapat mempengaruhi aktivitas bisnis. Disini dijelaskan bahwa laporan keuangan adalah produk dari akuntansi yang merupakan bahasa bisnis. Bahasa binis disini maksudnya adalah yang merubah dari transaksi bisnis menjadi informasi bisnis.

Adapun unsur dari laporan keuangan adalah: 1) Harta; 2) Utang; 3) Ekuitas; 4) Kinerja dan 5) Beban.

Harta

Harahap (2009) mendefinisikan harta sebagai sumber daya yang dikuasai oleh perusahaan yang berperan dalam operasi perusahaan.

Pendapat lain dikemukakan oleh Bambang (2014) bahwa ada dua tipe aktiva yaitu aktiva lancar dan aktiva tidak lancar, Aktiva lancar digunakan dalam siklus satu tahun dan aktiva tidak lancar digunakan lebih dari satu tahun.
Menurut Gill and Moira (2008) disebutkan bahwa harta adalah saldo debet yang berisi segala sesuatu yang dimiliki oleh perusahaan. Pendapat ini menitik beratkan pada kepemilikan kebendaan, lebih lanjut dibagi menjadi aktiva lancar dan aktiva tetap.

Menurut Harrison et. al. (2011), asset adalah sumber daya ekonomi yang menyediakan manfaat bagi suatu perusahaan di masa depan.

Dari beberapa pendapat tersebut diatas dapat diambil suatu kesimpulan bahwa harta adalah sumber daya ekonomi yang dimiliki oleh perusahaan yang dapat memberikan manfaat operasional perusahaan dimasa depan. Artinya sumber daya perusahaan tersebut dapat digunakan oleh operasional perusahaan dengan masa manfaat satu periode akuntansi atau lebih dimasa yang akan datang.

Utang didefinisikan oleh Harahap (2009) adalah kewajiban ekonomis dari suatu perusahaan yang diakui dan dinilai sesuai prinsip akuntansi.

Menurut Bambang (2014), utang dibagi menjadi dua tipe yaitu kewajiban lancar dan kewajiban jangka panjang. Kewajiban lancar adalah kewajiban perusahaan yang harus dibayarkan dalam jangka waktu satu tahun, sedangkan kewajiban jangka panjang adalah kewajiban perusahaan yang harus dibayarkan dalam jangka waktu lebih dari satu tahun.

Menurut Gill and Moira (2008) disebutkan bahwa Utang adalah saldo kredit yang berisi segala sesuatu yang menjadi kewajiban perusahaan.

Menurut Harrison et. al. (2011), utang adalah suatu kewajiban untuk membayar kepada suatu individu maupun organisasi.

Dari beberapa pendapat tersebut dapat dikemukan sebagai kesimpulan bahwa utang didefinisikan sebagai kewajiban yang dimiliki perusahaan dimasa kini sebagai hasil dari peristiwa masa lalu yang penyelesaiannya diharapkan dari hasil keuntungan ekonomis perusahaan.

Harahap (2009) memberikan pengertian bahwa ekuitas adalah hak yang tersisa atas aktiva suatu lembaga, dalam perusahaan ekuitas adalah modal pemilik. Selanjutnya Bambang (2014) memberikan pengertian bahwa ekuitas adalah modal yang mewakili kepemilikan pemegang saham.

Pendapat Gill dan Moira (2008) menyatakan bahwa selisih antara aktiva dengan kewajiban merupakan net worth yang sering disebut dengan modal pemegang saham.

Lebih lanjut Harrison et. al. (2011), menyebutkan bahwa klaim pemilik atas assets suatu korporasi disebut ekuitas pemegang saham. 
Dari beberapa pendapat tersebut diatas dapat digaris bawahi bahwa ekuitas dapat didefinisikan sebagai sisa atas harta-harta perusahaan setelah dikurangi dengan banyaknya kewajiban perusahaan. Harta, utang dan ekuitas merupakan elemen-elemen Neraca perusahaan.

Harahap (2009) memberikan gambaran bahwa revenue adalah hasil dari penjualan barang atau pemberian jasa yang dibebankan kepada langganan, atau mereka yang menerima jasa.

Selanjutnya Bambang (2014) menyebutkan bahwa pendapatan sering dikenal dengan penjualan yang merupakan sinyal bagi investor dan merupakan sasaran utama perusahaan.

Gill dan Moira (2008) berpendapat bahwa penjualan bersih adalah jumlah nilai seluruh kas atau penjualan kredit dikurangi dengan diskon dan rabat. Selanjutnya Harrison et. al. (2011) menyatakan bahwa pendapatan adalah kenaikan ekuitas pemegang saham akibat penyerahan barang dan jasa kepada pelanggan.

Dari beberapa pendapat tersebut dapat digaris bawahi bahwa penghasilan neto sering disebut sebagai ukuran kinerja. Penghasilan neto ini diperoleh dari adanya aktivitas perusahaan melalui penjualan, penghasilan jasa, bunga, deviden, royalti dan sewa. Di Indonesia, aktivitas penghasilan neto ini menimbulkan kewajiban pajak bagi perusahaan, baik yang dikenakan kepada konsumen maupun karena terjadinya laba usaha perusahaan. Kewajiban pajak ini dapat berupa pajak pertambahan nilai, pajak penghasilan dan pajak atas jasa profesional.

Beban

Menurut pendapat Harahap (2009), beban adalah semua biaya yang telah dikenakan dan dapat dikurangkan dari penghasilan.

Bambang (2014) menyatakan bahwa beban atau biaya itu dibagi menjadi dua yaitu harga pokok penjualan (cost of goods sold) dan biaya operasional yang terdiri dari biaya penjualan dan biaya administrasi dan umum.

Selanjutnya Gill and Moira (2008) berpendapat bahwa beban merupakan biaya-biaya yang dikeluarkan untuk menjalankan usaha.

Adapun Harrison et. al. (2011) berpendapat bahwa beban adalah biaya mengoperasikan suatu perusahaan.

Dari beberapa pendapat tersebut dapat dikemukakan bahwa beban didefinisikan sebagai biaya yang timbul akibat adanya aktivitas perusahaan untuk memperoleh laba. Untuk menggali informasi yang lebih mendalam dan luas, maka dikenal adanya bidang ilmu Analisis Laporan Keuangan. Analisis
Laporan Keuangan ini dapat memperluas dan mempertajam informasi yang disajikan dalam laporan keuangan. Analisis ini juga bisa menggali dan mengungkapkan berbagai hal yang tersembunyi dalam laporan keuangan. Hasil dari analisis ini dapat memberikan informasi tentang diagnosis, evaluasi dan prediksi keadaan ekonomi perusahaan.

\section{Rasio Keuangan}

Yanivi dan Nurwahyu (2004) mengilustrasikan pendapat John et. al (2004), bahwa analisis laporan keuangan merupakan bagian dari analisa bisnis. Analisa bisnis merupakan analisis atas prospek dan risiko perusahaan untuk kepentingan pengambilan keputusan bisnis.

Lebih lanjut Harahap (2009) mengemukakan bahwa analisis laporan keuangan berarti menguraikan pospos laporan keuangan menjadi unit informasi yang lebih kecil dan melihat hubungannya yang bersifat signifikan atau yang mempunyai makna antara satu dengan yang lainnya baik antara data kuantitatif maupun data non-kuantitatif.

Ciaran Walsh (2012) menyatakan bahwa rasio yang dikaji secara terpisah dengan rasio lainnya hanya memberikan informasi yang terbatas kepada kita.

Analisis laporan keuangan merupakan bagian penting dan tak terpisahkan dari analisis bisnis. Sasaran analisis bisnis adalah untuk meningkatkan pengambilan keputusan bisnis dengan mengevaluasi informasi yang tersedia tentang situasi keuangan perusahaan, manajemen, rencana maupun strategi. Analisis bisnis ini dapat digunakan bagi analis efek, penasihat investasi, manajer Reksa Dana, banker investasi, pemeringkat kredit, bangkir korporasi, maupun investor individual.

Dalam menganalisis laporan keuangan, tersedia berbagai alat yang dirancang oleh para ahli keuangan untuk memenuhi kebutuhan yang spesifik. Empat alat untuk menganalisis laporan keuangan tersebut adalah :
a. Analisa laporan keuangan komparatif
b. Analisa laporan keuangan common-size
c. Analisa rasio
d. Penilaian 
Tabel 1

Ringkasan analisis rasio keuangan

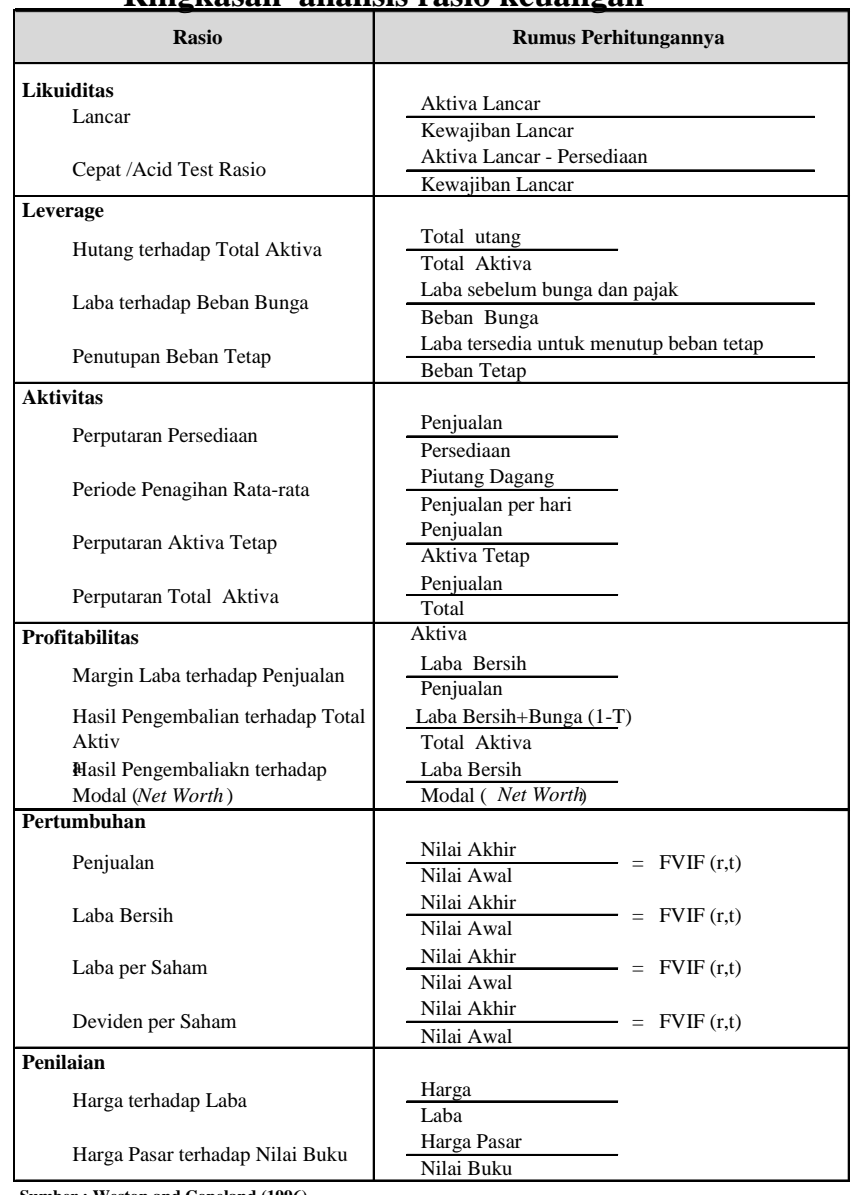

Variabel Independen

Sugiyono (2012) menyatakan bahwa variabel independen adalah sebagai variabel bebas dan sering disebut juga variabel stimulus, predictor, antecedent. Variabel independen merupakan variabel yang mempengaruhi atau menjadi sebab perubahannya atau timbulnya variabel dependen.

Variabel independen (variabel X) sebagai penyebab perubahan dari variabel dependen, dan karena variabel ini sebagai penyebab maka jumlahnya bias tak terhitung, sehingga dalam mengemukakan variabel independent ini harus terperinci dan jelas batasannya. Yang termasuk variabel independen seperti tersebut pada tabel diatas, dalam penelitian ini adalah:

1. Rasio Likuiditas $\rightarrow$ Current Ratio

2. Rasio Leverage $\rightarrow$ Debt Equity Ratio, Leverage Ratio

3. Rasio Profitabilias $\rightarrow$ Net Profit Margin, Return on Equity, Return on Assets, Earning Per Share

4. Rasio Aktivitas $\rightarrow$ Total Assets Turn Over
5. Rasio Penilaian $\rightarrow$ Price to Earning Ratio, Price to Book Value

6. Serentak semua rasio yang tersebut pada nomor 15

Variabel Dependen

Sugiyono (2012) menyatakan bahwa variabel dependen sebagai variabel output, kriteria, konsekuen dan terikat. Variabel ini dipengaruhi atau menjadi akibat, karena adanya variabel bebas.

Dalam penelitian ini variabel dependennya adalah return saham, yaitu diperoleh dari perubahan harga pasar ditambah dengan pendapatan per lembar saham. Perubahan harga saham dapat diformulasikan sebagai berikut:

$$
\begin{aligned}
& \text { Return Saham }=\frac{\mathrm{Pt}-(\mathrm{Pt}-1)}{\mathrm{Pt}-1} \\
& \begin{array}{l}
\text { Dimana } \\
\mathrm{Pt}=
\end{array} \\
& \mathrm{Pt}-1=\begin{array}{l}
\text { Harga pasar saham pada } \\
\text { sekarang }
\end{array} \\
& \begin{array}{l}
\text { Harga pasar saham pada periode } \\
\text { sebelumnya }
\end{array}
\end{aligned}
$$

\section{Kerangka Berpikir dan Hipotesis}

Kerangka Berpikir

Analisis rasio memberikan gambaran kepada calon investor untuk mengetahui lebih dalam kondisi perusahaan melalui Laporan Keuangan. Rasio baru memberikan indikasi saja, penyebab dan trennya perlu penjelasan dan kajian lebih lanjut. Melalui penjelasan Laporan Keuangan Perusahaan, media informasi yang digunakan perusahaan, pendapat pengamat bisnis, pengumuman di bursa saham dll., para calon investor dapat mengetahui lebih terperinci untuk mengetahui lebih dalam, sebagai jawaban atas rasio perusahaan, yang merupakan indikasi awal.

Hasil investasi tentunya sangat mempengaruhi para calon investor dalam memilih perusahaan, namun apakah rasio-rasio yang disajikan dalam laporan keuangan perusahaan tersebut memberikan petunjuk bagi investor untuk memperoleh hasil investasi yang diinginkan, hal ini perlu dilakukan penelitian lebih lanjut.

Berdasarkan latar belakang masalah, tujuan penelitian yang telah dikemukakan, bahwa yield (return saham) adalah tujuan akhir dari para investor dalam menentukan investasinya, maka kerangka konseptualnya dibuat sebagai berikut : 


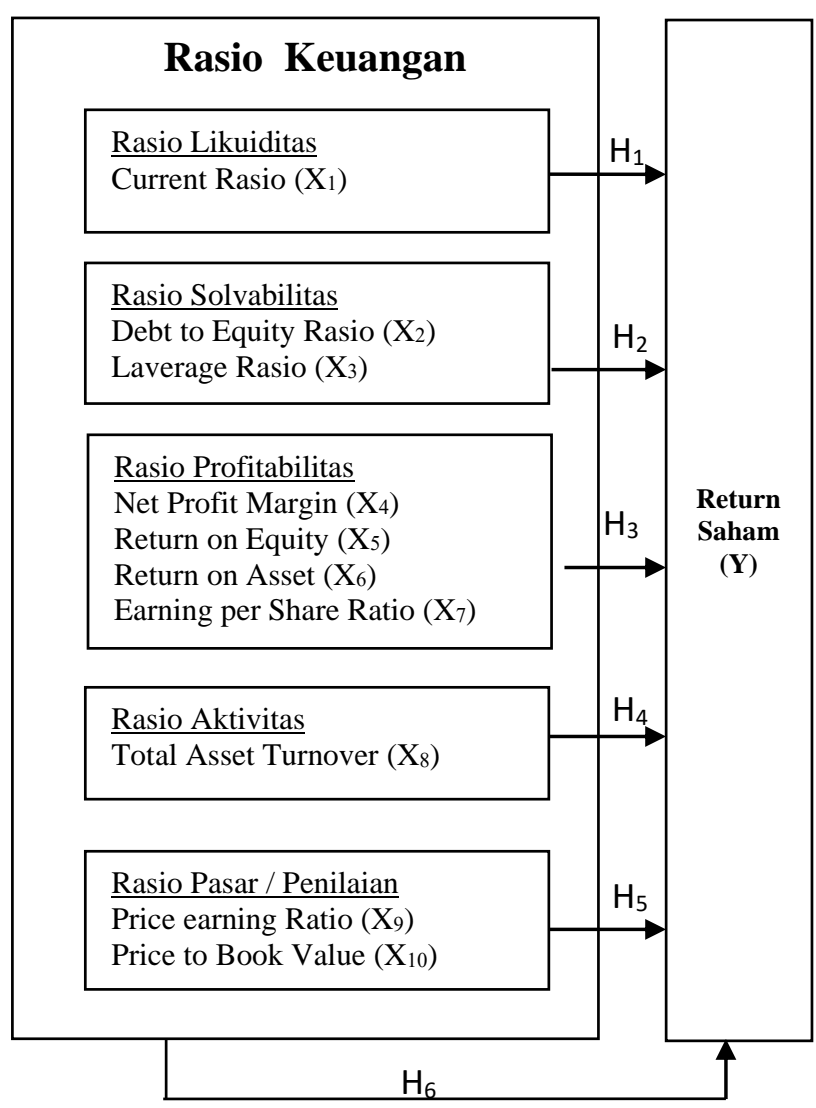

Gambar 1 Kerangka Berpikir

Hipotesis

Dari kerangka berpikir tersebut diatas maka dapat dikemukakan hipotesis sebagai berikut:

$\mathrm{H}_{1}$ : Rasio likuiditas berpengaruh terhadap return saham pada perusahaan semen yang sudah listing di Bursa Efek Jakarta.

$\mathrm{H}_{2}$ : Rasio solvabilitas berpengaruh terhadap return saham pada perusahaan semen yang sudah listing di Bursa Efek Jakarta.

$\mathrm{H}_{3}$ : Rasio profitabilitas berpengaruh terhadap return saham pada perusahaan semen yang sudah listing di Bursa Efek Jakarta.

$\mathrm{H}_{4}$ : Rasio aktivitas berpengaruh terhadap return saham pada perusahaan semen yang sudah listing di Bursa Efek Jakarta.

$\mathrm{H}_{5}$ : Rasio pasar berpengaruh terhadap return saham pada perusahaan semen yang sudah listing di Bursa Efek Jakarta.

$\mathrm{H}_{6}$ : Rasio keuangan secara simultan berpengaruh terhadap return saham pada perusahaan semen yang sudah listing di Bursa Efek Jakarta.

\section{METODOLOGI PENELITIAN}

\section{Tempat dan Waktu Penelitian}

\section{Tempat Penelitian}

Lokasi tempat penelitian ini adalah di Bursa Efek Jakarta. Lokasi ini diambil karena perusahan yang dianalisis telah menjadi Perseroan Terbatas yang terbuka, sehingga informasi yang diambil adalah bersifat umum dan mempunyai akurasi dan tingkat kepercayaan data yang tinggi.

Perseroan Terbatas yang sudah terbuka berkewajiban untuk mentaati peraturan-peraturan yang ada di Bursa Efek, Perpajakan, Pelaporan dan Badan Koordinasi Penanaman Modal. Selain itu dengan memperoleh data dari tiga perusahaan semen yang sudah terbuka tersebut maka produksi semen di Indonesia sudah terwakili, yaitu sebesar $85 \%$.

\section{Waktu Penelitian}

Waktu penelitian diambil dari data yang ada di Bursa Efek Jakarta melalui website www.idx.co.id berdasarkan laporan keuangan tiga tahun terakhir, yaitu tahun 2011, 2012 dan 2013. Data yang diperlukan peneliti dalam jangka waktu 5 (lima) tahun maka kekurangan data selanjutnya yaitu tahun 2010 dan 2009 diambil dari webside masing-masing perusahaan yaitu dari Semen Indonesia, Indosemen Tunggal Perkasa dan Semen Holcim.

\section{Metode Penelitian}

Sesuai dengan judul dari tesis ini, maka dalam penulisan tesis ini diperlukan data yang dapat memberikan informasi atau gambaran tentang masalah yang terkait dengan pokok bahasan.

\section{a. Desain Penelitian}

Penelitian ini merupakan penelitian kausal komparatif yang bertujuan untuk menganalisis pengaruh variabel bebas terhadap variabel terikat (Sugiyono:2012). Seberapa besar pengaruh rasio keuangan itu berpengaruh terhadap return saham, baik pengaruhnya secara individual per variabel bebas ataupun pengaruh secara serentak semua variabel bebas terhadap variabel terikat.

\section{b. Bentuk Penelitian}

Bentuk dari penelitian ini adalah kausal komparatif, maka akan dikemukakan hubungan antara variabel bebas dengan variabel terikat, bagaimana pengaruhnya antar variabel tersebut baik secara individual maupun secara bersama-sama.

Variabel yang dipergunakan dalam penelitian ini adalah Current Ratio (CR), Debt to Equity Ratio (DER), Leverage Ratio (LEV), Net Profit Margin 
(NPM), Return on Equity (ROE), Return on Asset (ROA), Earning per Share (EPS), Total Asset Turn Over (TATO), Price to Earning Ratio (PER) dan Price to Book Value (PBV) sebagai variabel bebas, disisi lain Return Saham sebagai variabel terikat.

\section{Populasi dan Sampel}

Populasi adalah keseluruhan kelompok orang, kejadian atau hal minat yang akan diinvestigasi, sedangkan sampel adalah bagian dari populasi (Sekaran:2006). Selanjutnya Darius Singpurwalla (2013) mengatakan, bahwa Population adalah " a set of units that is of interest to study". Dari penjelasan ini dapat diketahui bahwa populasi itu bukan hanya makhluk hidup saja tetapi juga ada yang bersifat peristiwa atau segala keingin dari si peneliti untuk memahami, mengetahui dan mendalami lebih lanjut tentang kaidah ataupun norma yang berlaku.

Sampel merupakan bagian dari populasi, artinya kita dapat mengetahui populasi dengan cara menggabungkan semua sampel sehingga diperoleh gambaran yang utuh atas populasi tersebut. Namun sering kali sampel ini hanya sebagian kecil dari populasi, sehingga perlu dilakukan pemilihan sampel yang benar-benar mewakili dari populasi. Sampel itu mempunyai ciri-ciri khusus, ciri khusus inilah yang kita sebut sebagai variabel.

Sesuai dengan latar belakang yang sudah dikemukan sebelumnya bahwa sampel yang diambil adalah berdasarkan jumlah produksi dari total ketiga perusahaan, yaitu PT Semen Indonesia Tbk, PT Indosemen Tunggal Perkasa Tbk. dan PT Holcim Tbk. Dari ketiga perusahaan yang sudah go public ini telah mewakili produsen semen di Indonesia sebesar $85 \%$.

\section{Proses Pengumpulan Data}

Proses pengumpulan data yang digunakan dalam peneltian ini adalah studi dokumentasi dengan cara mengumpulkan data sekunder yang diterbitkan oleh Bursa Efek Jakarta. Hasil data terakhir diperoleh dari laporan keuangan perusahaan semen yang sudah tercatat di bursa. Saat dilakukan unduhan Laporan Keuangan pada bulan Juni 2014 tersedia data tiga tahun terakhir yaitu tahun 2011. 2012 dan 2013. Adapun jenis data yang digunakan dalam penelitian ini adalah cross section untuk tiga perusahaan semen yang sudah terbuka dan data time series selama 5 (lima) tahun. Proses pengumpulan data ini sering disebut juga dengan data pooled cross section time series (Yuliansyah Noor : 2014).

\section{HASIL DAN PEMBAHASAN}

Hasil penelitian hipotesis dari $\mathrm{H}_{1}$ sampai dengan $\mathrm{H}_{6}$, dapat dilihat pada tabel berikut ini yang menggambarkan tabel hipotesis dari $\mathrm{H}_{1}$ sampai dengan $\mathrm{H}_{6}$ :

Tabel 2 Hipotesis dan hasil analisis

\begin{tabular}{|c|c|c|c|c|c|c|}
\hline $\begin{array}{c}\text { Hipo- } \\
\text { tesis }\end{array}$ & $\begin{array}{c}\text { Varia } \\
\text {-bel }\end{array}$ & Prob. F & Prob. t & $\alpha$ & Analisis & $\begin{array}{c}\text { Keputusa } \\
\mathrm{n}\end{array}$ \\
\hline $\mathrm{H}_{1}$ & CR & 0,1436 & 0,1436 & 0,05 & $\begin{array}{l}\mathrm{F} \text { dan } \mathrm{t} \\
>0,05\end{array}$ & $\begin{array}{c}\text { Model } \\
\text { regresi } \\
\text { ditolak }\end{array}$ \\
\hline $\mathrm{H}_{2}$ & $\begin{array}{l}\text { DER } \\
\text { LEV }\end{array}$ & 0,0109 & $\begin{array}{l}0,0050 \\
0,0039\end{array}$ & 0,05 & $\begin{array}{l}\mathrm{F} \text { dan } \mathrm{t} \\
<0,05\end{array}$ & $\begin{array}{l}\text { Model } \\
\text { regresi } \\
\text { diterima }\end{array}$ \\
\hline $\mathrm{H}_{3}$ & $\begin{array}{l}\text { NPM } \\
\text { ROA } \\
\text { ROE } \\
\text { EPS }\end{array}$ & 0,0893 & $\begin{array}{l}0,0750 \\
0,0124 \\
0,0679 \\
0,0724\end{array}$ & 0,05 & $\begin{array}{l}\mathrm{F} \text { dan } \mathrm{t} \\
>0,05\end{array}$ & $\begin{array}{c}\text { Model } \\
\text { regresi } \\
\text { ditolak }\end{array}$ \\
\hline $\mathrm{H}_{4}$ & $\begin{array}{c}\text { TAT } \\
\mathrm{O}\end{array}$ & 0,1891 & 0,1891 & 0,05 & $\begin{array}{l}\mathrm{F} \text { dan } \mathrm{t} \\
>0,05\end{array}$ & $\begin{array}{c}\text { Model } \\
\text { regresi } \\
\text { ditolak }\end{array}$ \\
\hline $\mathrm{H}_{5}$ & $\begin{array}{l}\text { PER } \\
\text { PBV }\end{array}$ & 0,5059 & $\begin{array}{l}0,2710 \\
0,7965\end{array}$ & 0,05 & $\begin{array}{l}\mathrm{F} \text { dan } \mathrm{t} \\
>0,05\end{array}$ & $\begin{array}{c}\text { Model } \\
\text { regresi } \\
\text { ditolak }\end{array}$ \\
\hline $\mathrm{H}_{6}$ & $\begin{array}{c}\text { CR } \\
\text { DER } \\
\text { EPS } \\
\text { LEV } \\
\text { NPM } \\
\text { PBV } \\
\text { PER } \\
\text { ROE } \\
\text { ROA } \\
\text { TAT } \\
\text { O }\end{array}$ & 0,5665 & $\begin{array}{l}0,6666 \\
0,7992 \\
0,6918 \\
0,8751 \\
0,3178 \\
0,8424 \\
0,5418 \\
0,9880 \\
0,4056 \\
0,1308\end{array}$ & 0,05 & $\begin{array}{l}\mathrm{F} \text { dan } \mathrm{t} \\
>0,05\end{array}$ & $\begin{array}{c}\text { Model } \\
\text { regresi } \\
\text { ditolak }\end{array}$ \\
\hline
\end{tabular}

Hipotesis Statistik

Untuk menentukan tingkat pengaruh antara variabel independen dengan variabel dependen, digunakan model analisis dalam bentuk persamaan regresi linier sebagai berikut:

1. Pada Hipotesis $1\left(\mathrm{H}_{1}\right)$ digunakan persamaan regresi linier sederhana sebagai berikut:

$\mathrm{Y}=\mathrm{a}+\mathrm{b}_{1} \mathrm{X}_{1}+\mathrm{e}$

2. Pada Hipotesis $2\left(\mathrm{H}_{2}\right)$ digunakan persamaan regresi linier berganda sebagai berikut: $\mathrm{Y}=\mathrm{a}+\mathrm{b}_{2} \mathrm{X}_{2}+\mathrm{b}_{3} \mathrm{X}_{3}+\mathrm{e}$

3. Pada Hipotesis $3\left(\mathrm{H}_{3}\right)$ digunakan persamaan regresi linier berganda sebagai berikut: $\mathrm{Y}=\mathrm{a}+\mathrm{b}_{4} \mathrm{X}_{4}+\mathrm{b}_{5} \mathrm{X}_{5}+\mathrm{b}_{6} \mathrm{X}_{6}+\mathrm{b}_{7} \mathrm{X}_{7}+\mathrm{e}$

4. Pada Hipotesis $4\left(\mathrm{H}_{4}\right)$ digunakan persamaan regresi linier sederhana sebagai berikut: $\mathrm{Y}=\mathrm{a}+\mathrm{b}_{8} \mathrm{X}_{8}+\mathrm{e}$

5. Pada Hipotesis $5\left(\mathrm{H}_{5}\right)$ digunakan persamaan regresi linier berganda sebagai berikut: $\mathrm{Y}=\mathrm{a}+\mathrm{b}_{9} \mathrm{X}_{9}+\mathrm{b}_{10} \mathrm{X}_{10}+\mathrm{e}$

6. Pada Hipotesis $6\left(\mathrm{H}_{6}\right)$ digunakan persamaan regresi linier berganda sebagai berikut: $Y=a+b_{1} X_{1}+b_{2} X_{2}+b_{3} X_{3}+b_{4} X_{4}+b_{5} X_{5}+b_{6} X_{6}$ $+b_{7} X_{7}+b_{8} X_{8}+b_{9} X_{9}+b_{10} X_{10}+e$ 


$$
\begin{array}{ll}
\begin{array}{ll}
\text { Dimana : } \\
\mathrm{Y}
\end{array} & =\text { Return Saham } \\
\mathrm{b}_{1} \mathrm{X}_{1} & =\text { Current Ratio }(\mathrm{CR}) \\
\mathrm{b}_{2} \mathrm{X}_{2} & =\text { Debt to Equity Ratio }(\mathrm{DER}) \\
\mathrm{b}_{3} \mathrm{X}_{3} & =\text { Leverage Ratio }(\mathrm{LEV}) \\
\mathrm{b}_{4} \mathrm{X}_{4} & =\text { Net Profit Margint Ratio }(\mathrm{NPM}) \\
\mathrm{b}_{5} \mathrm{X}_{5} & =\text { Return on Asset }(\mathrm{ROA}) \\
\mathrm{b}_{6} \mathrm{X}_{6} & =\text { Return on Equity }(\mathrm{ROE}) \\
\mathrm{b}_{7} \mathrm{X}_{7} & =\text { Earning per Share }(\mathrm{EPS}) \\
\mathrm{b}_{8} \mathrm{X}_{8} & =\text { Total Asset Turnover }(\mathrm{TATO}) \\
\mathrm{b}_{9} \mathrm{X}_{9} & =\text { Price to Earning Ratio }(\mathrm{PER}) \\
\mathrm{b}_{10} \mathrm{X}_{10} & =\text { Price to Book Value }(\mathrm{PBV})
\end{array}
$$

Pengaruh variabel independen terhadap variabel dependen diuji dengan tingkat kepercayaan (confident interval) $95 \%$ atau dengan tingkat significant level $(\alpha)$ sama dengan $5 \%$.

Dari hasil analisis diatas menggambarkan secara jelas bahwa pada kolom keputusan dapat dilihat bahwa dengan menggunakan tingkat $\alpha$ sebesar 5\% maka model yang bisa diterima adalah hipotesis $\mathrm{H}_{2}$ saja. Hasil analisis ini menggambarkan bahwa tingkat return saham dipengaruhi oleh besarnya Debt Equity Ratio dan Leverage Ratio. Dengan kata lain dapat dinyatakan bahwa tingkat Solvabilitas perusahaan Semen dapat mempengaruhi return saham perusahaan. Adapun faktor-faktor selain solvabilitas tidak akan mempengaruhi return saham.

Berdasarkan tabel tersebut diatas juga dapat diketahui bahwa jika kita menggunakan tingkat $\alpha$ sebesar $10 \%$ maka model regresi yang bisa diterima adalah hipotesis $\mathrm{H}_{2}$ dan $\mathrm{H}_{3}$. Artinya dengan menggunakan tingkat $\alpha$ sebesar $10 \%$ maka ada dua model persamaan yang dapat diterima dan mempengaruhi tingkat return saham yaitu persamaan pada hipotesis $\mathrm{H}_{2}$ dan $\mathrm{H}_{3}$. Hipotesis $\mathrm{H}_{2}$ menyatakan bahwa tingkat return saham dipengaruhi oleh besarnya Debt Equity Ratio dan Leverage Ratio (rasio solvabilitas). Sedangkan pada hipotesis $\mathrm{H}_{3}$ menyatakan bahwa tingkat return saham dipengaruhi oleh besarnya Net Profit Margin, Return on Assets Ratio, Return on Equity Ratio dan Earning per Share perusahaan. Hasil penelitian ini mendukung penelitian yang dilakukan oleh Azhari et al. (2016) yang menyatakan bahwa Debt Equity Ratio berpengaruh terhadap return saham.

Faktor fundamental perusahaan tidak selalu menjadi faktor pendorong dalam melakukan investasi pemilihan saham perusahaan. Penelitian ini belum mencakup return saham yang di pengaruhi oleh faktor-faktor diluar ratio-ratio keuangan (diluar faktor fundamental perusahaan), misal pengaruh tentang perluasan pasar produk, akuisisi perusahaan dan lain-lain.

\section{KESIMPULAN}

Berdasarkan analisis dan pembahasan terhadap hipotesis, maka dapat ditarik kesimpulam sebagai berikut:

a. Tingkat likuiditas perusahaan industri semen yang sudah go public, ternyata tidak berpengaruh terhadap besarnya return saham. Hal ini ditunjukkan dengan besarnya nilai probabilitas $\mathrm{F}$ (0.1436) maupun nilai probabilitas $\mathrm{t}(0.1436)$ lebih besar dari tingkat alfa $(0,05)$.

b. Rasio solvabilitas ternyata mempengaruhi besarnya peningkatan perolehan laba, hal ini ditandai dengan besarnya nilai $F(0,0109)$ maupun nilai t dimana DER $(0,0050)$ dan $\operatorname{LEV}(0,0039)$ lebih kecil dari nilai alfa $(0,05)$.

c. Hasil dari analisis terhadap rasio profitabilitas tidak berpengaruh terhadap perolehan return saham. Hal ini ditunjukkan dengan besarnya probabilitas nilai $\mathrm{F}(0,0893)$ maupun probabilitas nilai t secara serentak, yang ditandai dengan nilai NPM (0,075), nilai ROA (0,0124), nilai ROE $(0,0679)$ dan Nilai EPS $(0,0724)$ lebih besar dari nilai alfanya $(0,05)$.

d. Digambarkan juga bahwa rasio aktivitas usaha perusahaan, tidak berpengaruh terhadap return saham. Hal ini ditandai dengan besarnya probabilitas nilai $\mathrm{F}(0,1891)$ maupun nilai $\mathrm{t}$ $(0,1891)$ lebih besar dari nilai alfa $(0,05)$.

e. Analisis selanjutnya menunjukkan bahwa peningkatan rasio keuangan secara serempak tidak berpengaruh terhadap besarnya return perusahaan. Hal ini ditandai dengan tingkat probabilitas nilai $\mathrm{F}$ $(0,5059)$ dan probabilitas nilai t yang ditunjukkan pada nilai PER $(0,271)$ dan nilai PEV $(0,7965)$ lebih besar dari nilai alfa $(0,05)$

f. Analisis dengan menggunakan tingkat kepercayaan ( $\alpha=10 \%$ ), maka hipotesis yang diterima menjadi dua, yaitu hipotesis 2 (tingkat solvabilitas berpengaruh terhadap return saham) dan hipotesis 3 (tingkat aktivitas berpengaruh terhadap return saham). Adapun Hipotesis yang ditolak adalah hipotesis 1 , hipotesis 4 , hipotesis 5 dan hipotesis 6. 


\section{REFERENSI}

Azhari, A. et. (2016). Pengaruh ROE, DER, TATO dan PER terhadap Harga Saham Perusahaan Properti dan Real Estate yang Go Publik di Bursa Efek Indonesia. JAB Vol 32 No 2, 32(Jurnal Administrasi Bisnis).

Gill, J. O. E. al. (2008). Understanding Financial Accounting. San Fransisco: Crisp Publication Inc.

Harahap, S. S. (2009). Analisa Kritis Laporan Keuangan. Teori Akuntansi. https://doi.org/www.rajagrafindo.com

Horrison Jr, W. T. \& H. (2011). financial Accounting (8th ed.). Singapore: Pearson Education Inc.

Indonesia, B. (2013). kinerja industri semen diatas rata-rata, p. 13. Retrieved from url

Juan, N. E., \& Wahyuni, E. T. (2012). Panduan Praktis Satandar Akuntansi Keuangan.

Noor, Y. (2014). Analisis Data Penelitian Ekonomi \& Manajemen (1st ed.). Jakarta: Grasindo.

Singpurwalla, D. (2013). A Handbook of Statistics an overview of statistik Methods (Bookboon.c). Bookboon.com. Retrieved from Bookboon.com

Sugiyono. (2012). Metode Penelitian Kuantitatif, kualitatif dan $R$ \& $D$ (16th ed.). Bandung: Alfabeta.

Wahyudiono, B. (2014). mudah membaca laporan keuangan (1st ed.). jakarta: raih asa sukses.
Walsh, C. (2012). Key management Ratios the clearest guide to the critical numbers that drive your business (4th ed.). Dublin: Pearson Education Limited.

Weston,J, F. (1996). Essential Of Managerial Finance. Financial Management. Retrieved from

http://oald8.oxfordlearnersdictionaries.com/dict ionary/detrimental

www.idx.co.id. (n.d.). Retrieved from www.idx.co.id

Yanivi S, B. et. al. (2004). Analisis Laporan Keuangan. (S. Empat, Ed.). Jakarta: salemba empat.

\section{PROFIL PENULIS}

Penulis lahir di Boyolali, sebuah kota kabupaten di daerah Jawa Tengah dan bersekolah di SDN V boyolali dilanjutkan ke SMPN III Boyolali serta menamatkan SLTA nya di SMAN 1 Boyolali tahun 1983/1984. Selanjutnya penulis merantau ke Jakarta untuk kuliah sambil bekerja dan meyelesaikan S1 nya di STIE 'YAI'. Dan sejak tahun 2004 mengajar di Universitas Bina Sarana Informatika, Karawang sampai dengan sekarang. 